\title{
LISTINGS OF UNCATALOGED COLLECTIONS
}

Fred L. BELLOMY: Head, and Lies N. JACCARINO: Systems Analyst, Library Systems Staff, University of California, Santa Barbara, California.

An operational computerized system used by the UCSB Libraries produces listings of bibliographic data about items in collections where full cataloging treatment is not considered justified. The system produces listings of the brief bibliographic records sorted by any of the data elements in the record including up to twenty-five subjects terms. Of special interest are the authority listings of descriptions and the coordinate indexes to the full records.

\section{INTRODUCTION}

This short report was extracted from the more comprehensive document, Listings of Uncataloged Collections-Systems Documentation, Santa Barbara: University of California, December 1969, Library Systems Document LS 69-11.

The Library Staff at the University of California at Santa Barbara is using computerized procedures to produce a variety of listings of bibliographic information about items in uncataloged collections. Although many similar systems undoubtedly have been developed to do similar jobs, this one is noteworthy in two respects, first in being well-documented and second because its versatility has been tested on three totally different collections. The machine programs, written in PL/I, were first used to list the UCSB Art Exhibition Catalogs Collection, but they were designed to be versatile so that they could be applied easily to other similar collections 
as well. At present these programs are also being used at UCSB to list the documentation of marine pollution due to major oil spills (The Oil Spill Information Center). The programs have been successfully tested also on about one hundred items of the UCSB collection of Early American Trade Catalogs. Application to other collections (such as the phono record collection or video tape file) has been studied and is feasible.

Although it is usually difficult to use programs that were not specifically tailored for a particular user, these programs represent at least one instance where attention to versatility and the probable broad scope of possible applications has resulted in a system capable of producing listings for different collections at any location where there is access to an IBM System 360 Computer and a staff capable of adapting about a half dozen Job Control Language (JCL) statements.

The machine written listings of catalogs provide a limited amount of bibliographic data about each item in the collection. The advantage of such listings is the expedition with which a new, not-yet-cataloged, collection can be made accessible.

\section{DESCRIPTION}

As a first step in obtaining a listing, library staff members examine each item in the collection to be listed and transcribe the necessary bibliographic data to an input work sheet (Figure 1).

Information on the work sheet is keypunched into one or more punched cards. These records, once in the computer, can be sorted in various ways to provide a variety of listings. Master listings can be produced at desired intervals (e.g. monthly). Multiple copies of each list can be produced, and the sheets of computer printout are a convenient form of access to the material when individual copies of the list are separated and placed in hard-board binders for distribution to the Library Service Desks.

Program "packages" (i.e. JCL decks) contain many comment cards, so that each package is self explanatory after very little instruction. To keep the system simple for the librarians who use it, separate "packages" have been prepared for each different listing (or combination of listings) decided on. Listings of the full records (see Figure 2) have been prepared now by 1) classification letter, 2) accession number, 3) year of "exhibit", 11) main and secondary subjects, 12) agency name, 13) agency city, and 17) author. Obviously, others are possible. Listings of subjects (Figure 3) and agencies with the number of times each was used accompany full record listings by subject and agency. These are used as authority lists for future term assignments. Another package, ARTINDX, is used to produce coordinate indexes by subject, agency, author and others. An example of the subject index is shown in Figure 4. Such indexes are used with a master listing of the full bibliographic records in accession number order. This method reduces the amount of printout required to provide many different description approaches to the collection. 


\section{CATALOG COLLECTIONS \\ Input Worksheet}

\begin{tabular}{|c|c|c|}
\hline & 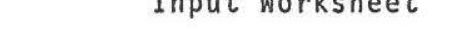 & Column \\
\hline 1. & Classification letter & $2-3$ \\
\hline 2. & Accession Number & $4-8$ \\
\hline 3. & Year of Exhibit & $9-12$ \\
\hline 4. & B\&W Illustration No. & $13-15$ \\
\hline 5. & Color Illustration No. & $16-18$ \\
\hline 6. & Chronology $(Y=$ yes, $N=$ no $)$ & 19 \\
\hline 7. & Bibliography No. Pages & $20-21$ \\
\hline 8. & Bib.Ft. Notes $(Y=$ yes, $N=$ no $)$ & 22 \\
\hline 9. & Pages No. & $23-25$ \\
\hline 10. & Spare & $26-30$ \\
\hline 11. & Subject(s) (separate wi & ;") Var \\
\hline
\end{tabular}
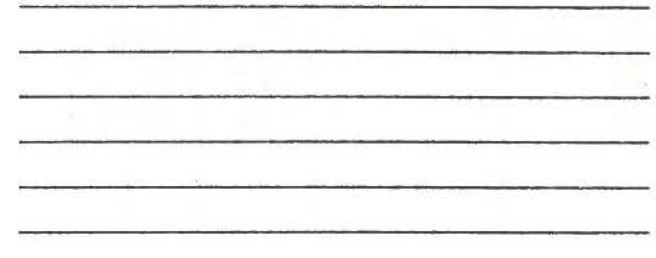

12. Agency name_ Var

13. Agency City_ Var

14. Agency State_ $\operatorname{Var}$

15. Agency Country_ Var

16. Title_ $\operatorname{Var}$

17. Author Var

18. Spare Var

Note: Data elements 1-10 are fixed field and are to be keyed into the card columns indicated. The card sequence number is always keyed into column 1. Data elements 11-18 are variable field and each is to be terminated with a " ". Every record must contain exactly eight of these end of variable field marks ("-").

Fig. 1. Input Worksheet for Catalog Collections. 
BRITISH MUSEUM LONDON, GREAT BRITAIN

BRITISH MUSEUM LONDON, GREAT BRITAIN

FITZWILLIAM MUSEUM CAMBRI DGE, GREAT BRITAIN

MAGGS BROS. LONDON, GREAT BRITAIN KLEINBERGER, F., GALLER IES NEW YORK, NEW YORK USA

DROUOT, HOTEL PARIS, FRANCE

NATIONAL LOAN COLLECTION T RUST

LONDON, GREAT BRITAIN

BELVEDERE

VIENNA, AUSTRIA

DROUOT, HOTEL PARIS.FRANCE

MAGGS BROS. LONDON, GREAT BRITAIN

NATIONAL MUSEET COPENHAGEN, DENMARK
933 BRITISH MUSEUM, LONDON, GREAT BRITAIN, COLLECTIONS, HANOBOOKS MANUALS ANO GUThes

LONDON, GREAT BRITAIN, GALLERIES AND MUSEUMS, COLLECT TONS; BRONZE AGE, EUROPEAN, COLLECTIONS BRON.ES, EUROPEAN, COLLECTIONS:

773 BRITISH MUSEUM, LONDON, GREAT BRITAIN, COLLECTIONS, HANDBCOKS MANUALS AND GUIDES;

LONDNN, GREAT BRITAIN, GALLERIES AND MUSEUMS, COLLECTIONS, HANDBOOKS

MANUALS AND GUIDES;

ART, EGYPTIAN, COLLECTIONS

774 FITZWILLIAM MUSEUM, CAMBRIDGE, GREAT BR ITAIN, COLLECT IONS, HANDBNOKS MANUALS AND GUIDES:

CAMBRIDGE, GREAT BRITAIN, GALLER IES MANURS AND GUILES TONS, HANDBOOKS

670 GRAPHIC ARTS

701 PAINTING, ITALIAN, 15TH CENTURY; CHARITIES, AMERICAN, 20 TH CENTURY; PAINTING, ITALIAN, 16TH CENTURY; WOPLD WAR, 1914-1918, CHARITIES,

AMERICAN
72 SAINT-AUBIN, GABRIEL JACQUES DE, 1724 1780 ; GRAPHIC ARTS, FRENCH, 18 TH CENTURY

789 NATIONAL LOAN COLLECTIION TRUST, LONDON, GREAT BRITAIN, COLLECTIONS, HANDBDOKS MANUALS AND GU LONDON, GREAT BRTYAIN, GALLERIES AND PAINTING, CDLLECTIONS

224 TAPESTRY, GOBELIN

70 UHOE, WILHELM, 1874-1947; COLLECTORS ANO COLLECTING,20TH CENTURY

669 GRAPHIC ARTS

641 MANET,EDOUARD,1832-1883; PAINTING,FRENCH, 19 TH CENTURY
$158 P$ (153 BEW ILLUS, 1 COLOR ILLUS, INC. CHRONOLOGY) AUTHOR: REA), CHARLES A.:SMITH,REGINALD; TITLE: GUIDE TO THE ANTI 2UITIES JF THE EARLY BRONZE AGE DF CENTRAL AND

(1909) 325P 1233 B\&W ILLUS, 1P BIBLIOGRAPHY, FOOTNOTES, INC. CHRONOLOSYI AUTHOR: BUNGE, E,A.WALLIS; TITLE: GUIDE TO THE EGYPIIAN COLLECTIONS IN THE BRITISH MUSEUM

(1912) $240 P(223$ BEW ILLUS) TITLE: PRINCIPAL PICTURES OF THE FITZWILLIAM MUSEUM, CAMBRIDGE

1915) 105 P (27 BEW ILLUS) TITLE: ENGRAVINGS,ETCHINGS AND DRAWINGS (CATALOGUE "34?

(1917) 260P (102 BEW ILLUS, 3P BIBLIOGRAPHY, FDOTNOTES) AUTHOR : SIREN, JSVALO;BROCKWELL, MAURICE W.; TITLE: LOAN EXHIBITION OF ITALIAN PRIMITIVES IN AID DF THE AMERICAN WAR RELIEF

(1919) $63 P$ (40 BEW ILLUS, FOOTNOTES) TITLE: EAUX-FORTES ORIGINALES, GRAVURES, DESSINS, LIVRES ET CATALOGUES

(1919) 113P I 53 BEH ILLUS, IP BIBL IOGRAPHY, FOOTNOTES, INC. CHRONOLOSYI TITLE: CATALOGUE OF PICTURES IN THE CHAT IONAL LOAN COLLECTION TRUST, LONDON

(1921) $71 P$ 124 BEH ILLUS, FOOTNOTES) AUTHOR: BALDASS,LUDWIG VON; TITLE: KATALOG DER GOBELINS-AUSSTELLUNGIPART 2 OF A HORK IY 3 PARTSI

$11921) 12^{P}$ (16 3EW ILLUS) TITLE: CATALOGUE DES TABLEAUX: AQUARELLES, DESSINS, COLLECTION UHDE, SALLE N.1.

(1922) 146P ( 42 BEW ILLUS) TITLE: ENGRAVINGS, ETCHINGS AND DRAWINGS (CATALOGUE \#430)

(1922) 36P (7 BEW TILLUS, IP BTBLTOGRAPHY, FOOTNOTES) TITLE: EDOUARO MANET CUTSIALLNING AV HANS ARBETEN SKA ND INAVISK AGD)

Fig. 2. Sample Listing of Full Record. 


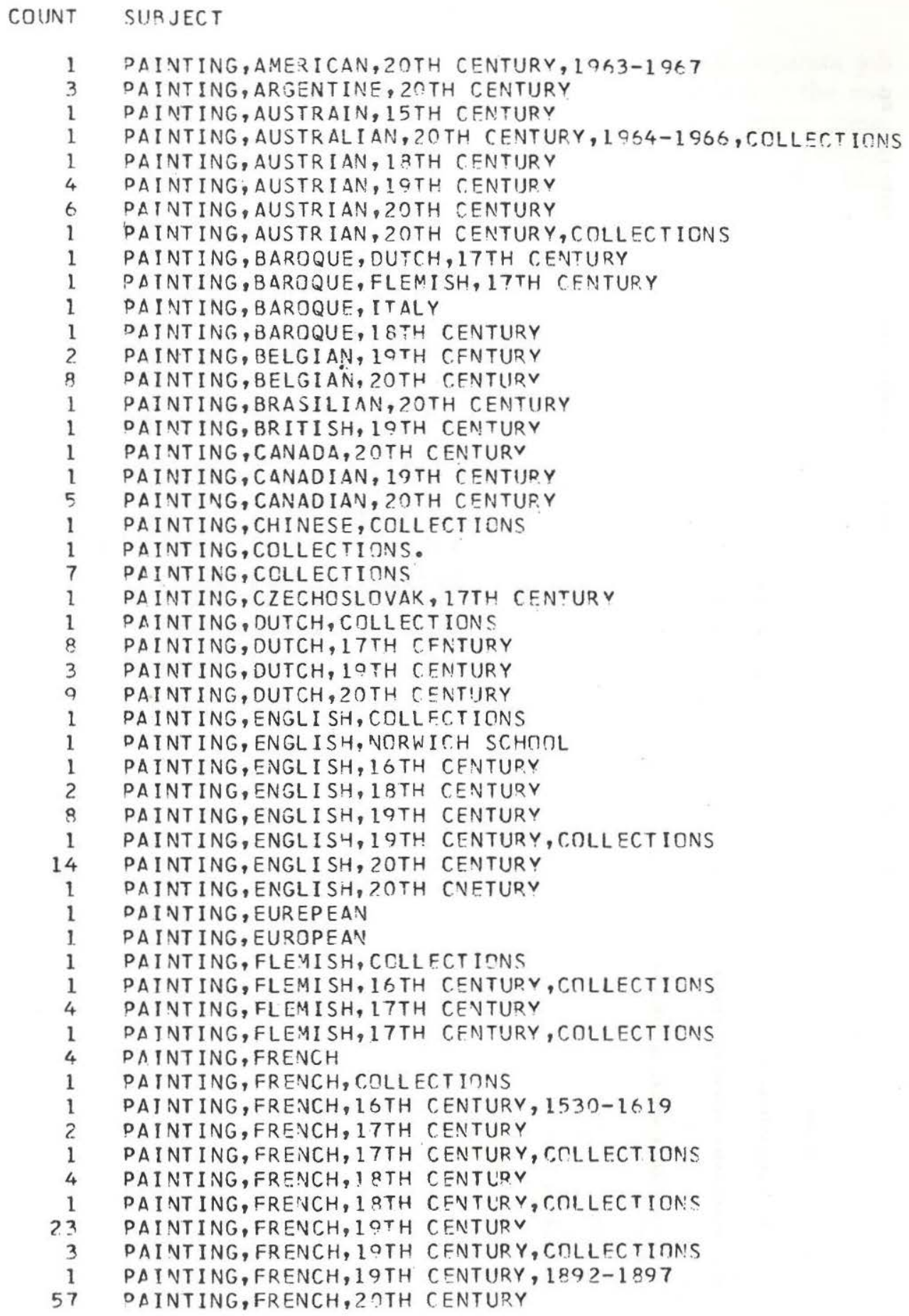

Fig. 3. Subject Listing. 
CIL IMPORTS.HISTORY

OIL IMFCATSORESTRICIALAS

OIL IN NAVIGABLE WATERS ACT (1922)

JC 1100

OIL IN NAVIGable WATERS ACT. AMENDMENTS (1963)

JC 1100

OIL LANOS

OIL LEAKAGE

OIL LEAKS

OIL POLLUTION

Fig. 4. Coordinate Index of Subjects.

JU 0160 J0 1100
NE 0603

Jo 0129

GP 0068

Jo 0038

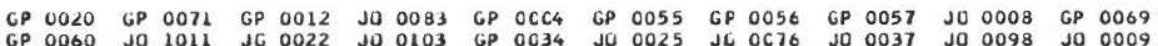

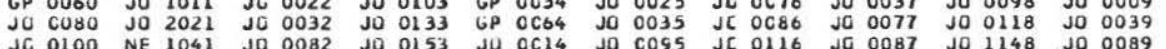

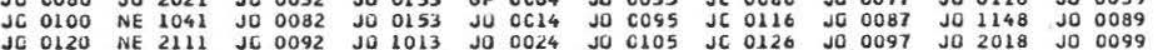

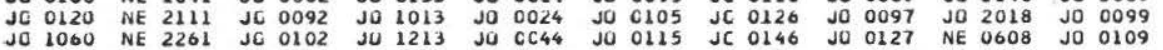

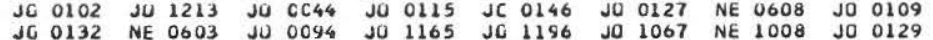
JO 1002 NE 1013 JO 0104 JU 2025 JE 2036 JO 1297 NE 1088 JO 0199 JC 1012 NE 1053 JO 0154 JO 2065 NE 2016 NE 0607 NE 2048 Jo 1209 JO 1092 NE 1073 JU 1 C14 NE 0615 NE $21 C 6$ NE 1067 NE 2088 JO 1229 JC 1182 NE 2003 JU 1 C44 NE 2035 NE 2246 NE 2097 NE 2188 J0 1299 JC 2002 NE 2083 JO 1 C54 NE 2045 NE 225E NE 2257 NE 2228 NE 0609 JO 2032 NE 2093 JO 1 C64 NE 2085 NE 2256 NE 2317 NE 2248 NE 1049 NE 0602 NE 2103 JO 1084 NE 2095 NE 2356 NE 2317 NE 2258 NE 1069 33 NE C614 NE 2295

NE 2042 NE 2243 NE 1064 RE COOS

NE 2052 NE 2303 NE 2014 RE 0035

NE 2092 NE 2313 NE 2 C84

NE 2102 NE 2753 NE 2094

NE 2212 PA 0003 NE $211 \mathrm{C}$

\begin{tabular}{lll} 
NE 2892 & RE 0033 NE 2114 \\
PA 0002 & NE 2264 \\
\hline & & NE
\end{tabular}

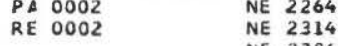

NE 23834

NE 2774
윰

हి

$\underset{0}{2}$

$\underset{10}{\infty}$

$\forall$
8
0
0
0
0
0
0
0
0 


\section{COMPUTER PROGRAM}

The computer program for the listings consists of several separate job steps. The job step, ARTREAD, which reads the data cards into the machine, prepares a file in correct form for the sorting and printing steps. ARTREAD will also prepare the master file on disk for further processing.

The second step, SORTD, is a standard utility program in the IBM Computer Library. It sorts records according to specifications on one of the cards in the program package. The third job step, ARTPRNT, prints the listing. This program is so designed that it can print either the agency field or the subject field on the left-hand side of the page; it also permits printing or omitting agency state or agency country, or both. A completely separate program, called ARTUPDT, enables the Librarian to update the master file periodically. It allows addition and deletion of records and changes in records already listed.

A special feature of the ARTREAD program is worth mentioning. The input record has room for five separate subjects and each subject has room for five separate subdivisions. It is possible to specify an option in ARTREAD whereby the subjects in the subject field are rotated so that separate records are created, each with a different subject in the first field. This option would make up to five records out of one. There is also an option enabling a maximum of 25 records to be made out of one, whereby each subject subdivision is printed in the first position in the subject field. These two options are of importance when subject sorting takes place; the latter one is of particular use when subject indexes are printed. An example of the way these options operate is shown below.

The original data in field 11:

DADAISM, FRENCH, 20th CENTURY;

DUCHAMP, MARCEL, 1887-1968

Option 0 will file the original record as:

DADAISM, FRENCH, 20TH CENTURY;

DUCHAMP, MARCEL, 1887-1968

Option 1 will file the same as Option 0 and in addition it will file:

DUCHAMP, MARCEL, 1887-1968;

DADAISM, FRENCH, 20TH CENTURY

Option 2 will file the same as Option 1 and in addition it will file:

FRENCH, 20TH CENTURY, DADAISM;

DUCHAMP, MARCEL, 1887-1968

20TH CENTURY, DADAISM, FRENCH;

DUCHAMP, MARCEL, 1887-1968

MARCEL, 1887-1968, DUCHAMP;

DADAISM, FRENCH, 20TH CENTURY

1887-1968, DUCHAMP, MARCEL;

DADAISM, FRENCH, 20TH CENTURY 
Option 3 may be used when producing an author listing. When this option is specified, a separate record is created for each second, third, etc. author in permuted order. For example, when field 17 contains:

AUTHOR: LIPCHITZ, JACQUES; GRIS,

JUAN; TITLE: JUAN GRIS 1887-1927.

Option 3 creates the additional record:

AUTHOR: GRIS, JUAN; LIPCHITZ, JACQUES

TITLE: JUAN GRIS 1887-1927.

The length of each record is variable, with a limit of 1,223 characters per record, a number arrived at by summing the maximum field lengths observed in a sample of 100 typical records.

Detailed listings of the programs and program packages (JCL) are available at the UCSB Library Systems Office.

\section{IMPLEMENTATION}

The program packages mentioned earlier were designed for user convenience. A program package is a deck of control cards (IBM JCL) that call on the stored programs, ARTREAD, SORTD, ARTPRNT, ARTUPDT and ARTINDX when needed, and include all the options required for a particular type of listing. The program package with a current heading card in place and punched data cards inserted is ready for submission to the computer. Such a package for an update run is shown in Figure 5.

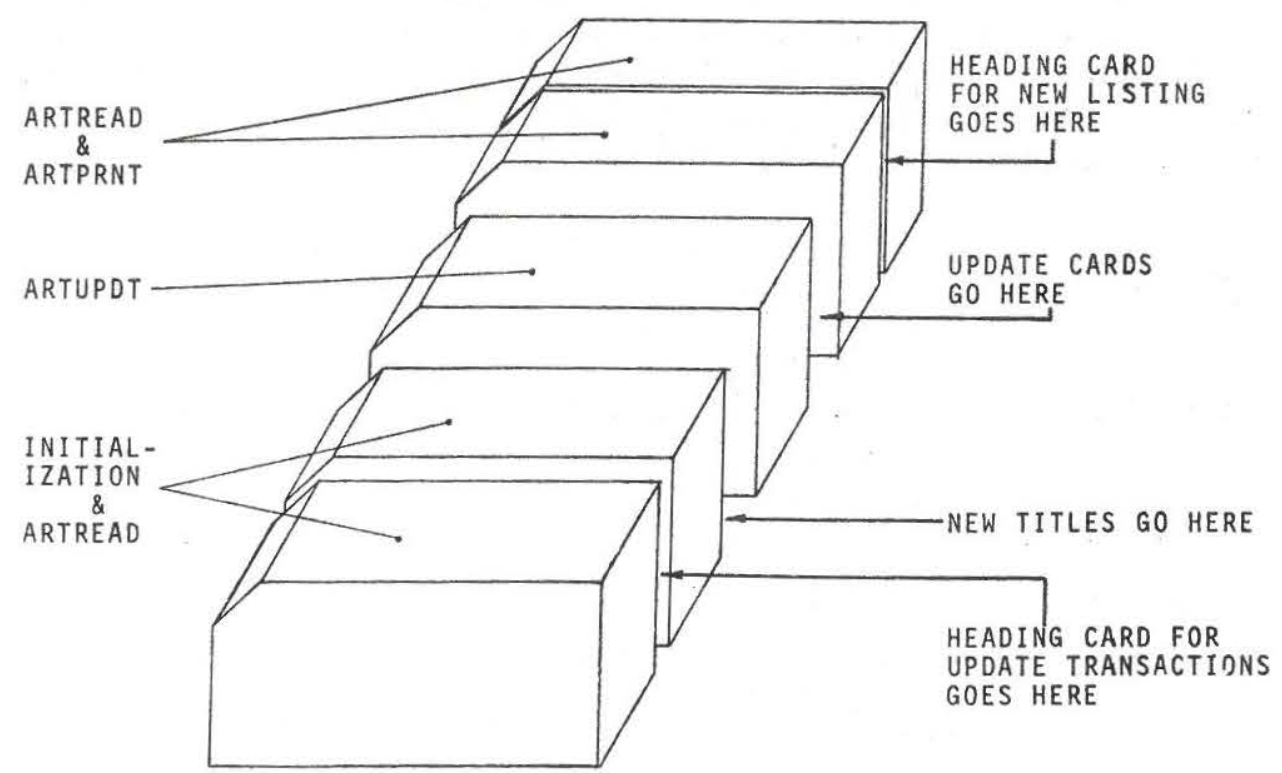

Fig. 5. ARTUPDT Program Package.

\section{CONCLUSION}

This classical systems development effort has demonstrated that highly versatile systems capable of meeting a wide range of requirements can be 
developed when attention is given to the full scope of requirements the new system may be called upon to meet. That the new computerized procedures are in fact satisfying diverse needs is attested to by the following two statements from Librarians using the machine produced lists with different uncataloged collections: Virginia Smith, Arts Library, says:

"This system of listing Art Exhibition Catalogs has several advantages.

The access to each catalog is so much greater than in a standard cataloging system that the regular method seems antiquated. Each catalog can be retrieved by almost any kind of information - author, title, date, agency (sponsoring or exhibiting institution), city, country, or one of the possible twenty-five subject descriptors. The economy is another advantage - there is a $40 \%$ increase in production over the standard cataloging. The processing is simpler and faster, and the end product (computerized printout) is a facile tool adaptable for any level of patron, freshman to doctoral candidate."

Maria Patermann, Oil Spell Information Center, reports:

"The base of our retrospective search module consists of more than 10,000 citations to a wide range of library materials (journal articles, photographs, newspaper clippings, aerial photographs, maps, films, tapes, texts and monographs) related to major oil spills. The data base is expected to grow to 100,000 items. All material is indexed at an average level of 9.5 terms per item using a controlled vocabulary (theasaurus) of our own design which must satisfy a wide range of user needs.

The system of producing selective listings can serve well. Its major advantage is providing access to a multi-discipline, multiform collection and the elimination of duplicate processing operations. The multiple subject entries make it unnecessary to obtain more than one copy of any document. The reduction of search time and the flexibility of refining the thesaurus with a built-in weeding capability are the most important benefits for our growing collection. Input can be prepared by non-professionals - an economic advantage which offsets, to some extent, the cost of keypunching operations. This automated system is expected to become an attractive customer service in that it gives a dynamic impact of selected information from a large data bank."

\section{ACKNOWLEDGMENTS}

The system described in this document is the work of many hands, and without the encouragment of the University Librarian, Donald C. Davidson, and the Assistant University Librarian - Services, Eugene E. Graziano, and the enthusiasm of the Head of the Arts Library, William R. Treese, these programs might never have been developed. 